\title{
Intake, digestibility and intake behaviour in cattle fed different levels of palm kernel cake
}

\section{Consumo, digestibilidad, y comportamiento ingestivo del ganado alimentado con diferentes niveles de torta de palma}

\author{
Ana Carolina Fereira, ${ }^{1 *}$ M.Sc, Ronaldo Lopes $0,{ }^{1}$ Ph.D, Adriana Regina B, ${ }^{2}$ Ph.D, Gleidson \\ Giordano Pinto de C, ${ }^{1}$ Ph.D, Raimundo Nunes Vaz S, ${ }^{1}$ Ph.D, Paulo Andrade O, ${ }^{2}$ M.Sc.
}

${ }^{1}$ Universidade Federal da Bahia, Salvador, BA. Animal Science Dept, EMEV. ${ }^{2}$ Universidade Federal do Recôncavo da Bahia, UFRB/Cruz das Almas-BA. *Correspondence: caroltecnia@gmail.com

Recibido: Diciembre de 2011; Aceptado: Marzo de 2012.

\begin{abstract}
Objective. The potential use of palm kernel cake was evaluated as a replacement for soybean and corn meal in cattle feed, by investigating their intake, digestibility levels and the intake behaviour of cattle fed diets containing different levels of palm kernel cake concentrate. Materials and methods. The experiment was conducted at the Experimental Farm of the Federal University of Bahia, between August and October 2009. Five crossbred Holstein $\times$ Zebu adults, were used. A $5 \times 5$ Latin square experimental design was used. The animals were fed Tifton-85 Bermudagrass, which made up $65 \%$ of their diet, plus one of five different levels of palm kernel cake concentrate $(0,7,14,21$ and $28 \%)$. Results. A linear decrease in dry matter $(\mathrm{kg} / \mathrm{day})$ was observed due to the lower palatability and higher fiber content of the palm kernel cake. Neutral detergent fiber intake by the animals showed a quadratic behavior. The coefficients of fractional digestibilities of the analyzed feed, did not differ due to the inclusion of palm kernel cake. The ingestive behavior of the animals was not influenced by the inclusion of palm kernel cake in the diet. Conclusions. Palm kernel cake can be used as an alternative feed supplement in ruminant production systems to reduce feed costs without changes in the studied variables.
\end{abstract}

Key words: Biodiesel, by-products, feeding, neutral detergent fibre, ruminant (Source: $C A B$ ).

\section{RESUMEN}

Objetivo. Se evaluó el uso potencial de la torta de palma como sustituto de harina de soja y harina de maíz en la alimentación del ganado mediante el estudio de su consumo, niveles de digestibilidad y el comportamiento ingestivo de los bovinos alimentados con dietas con diferentes niveles de torta de palmiste. Materiales y métodos. El experimento se realizó en la Granja Experimental de la Universidad Federal de Bahía, entre agosto y octubre de 2009. Cinco animales cruzados Holstein $x$ Cebú, fueron utilizados. Se utilizó un diseño experimental de cuadrado latino $5 \times 5$. Los animales fueron alimentados con heno de Tifton-85 Bermuda (65\% de la dieta). Además, cinco niveles diferentes de concentrado de palma torta de palmiste $(0,7,14,21$ y $28 \%)$. Resultados. Se observó una 
disminución lineal en la materia seca ( $\mathrm{kg} / \mathrm{día}$ ) debido a la palatabilidad inferior y al contenido de fibra superior de la torta de palmiste. La ingesta de fibra en detergente neutro por los animales mostró un comportamiento de segundo grado. Los coeficientes de digestibilidad fraccional de los alimentos analizados no fueron diferentes debido a la inclusión de la torta de palma. El comportamiento ingestivo de los animales no fue afectado por la inclusión de hasta $28 \%$ de torta de palma en la dieta. Conclusiones. La torta de palma se puede utilizar como un suplemento alimenticio alternativo en los sistemas de producción de rumiantes para reducir los costos de alimentación, sin cambios de las variables estudiadas.

Palabras clave: Alimentación, biodiesel, fibra en detergente neutro, rumiantes, subproductos (Fuente: CAB).

\section{INTRODUCTION}

Co-products are used in ruminant feed to minimize production costs. Cakes from the extraction of biodiesel have qualitative characteristics satisfactory for use as a feed supplement. The use of these cakes in animal feed, also prevents the possible inefficient disposal of these wastes and its consequent damage to the environment.

Palm kernel cake, resulting from the extraction of palm oil, is a good alternative feed for ruminant animals. This ingredient has a high concentration of fiber and protein, thus it can reduce costs and achieve satisfactory animal performance (1).

Assessment of the nutritional value of feed is the basis for the formulation of diets, especially when the incorporation of new feed into ruminant diets is required. Furthermore, knowledge of the amount of dry matter intake is important to ensure the availability of the proper nutrients for an animal's physiological processes, and consequently productive performance.

The co-products used in traditional feed such as soybean and corn meals can affect the intake and digestibility of feed and microbial activity in the rumen. Thus, consumption and digestibility measures are the most important parameters for assessing the nutritional value of new ingredients (2).

The aim of this study was to evaluate the potential use of palm kernel cake as a feed supplement for cattle and its best level of inclusion in the diet by investigating consumption and digestibility of the feed and intake behaviour and response to bio-climatological variables of Holstein-Zebu cattle.

\section{MATERIALS AND METHODS}

Study site. The experiment was conducted at the Experimental Farm of the Federal University of Bahia, located in São Gonçalo dos Campos, Bahia, in the region of Recôncavo and is characterized by a mean annual temperature of $26^{\circ} \mathrm{C}$, relative humidity of $85 \%$, and annual precipitation of about $1200 \mathrm{~mm}$. This experiment was udertaken during the period between August and October 2009, comprising an experimental period of 55 days.

Animals and treatment. Five crossbred Holstein $\times$ Zebu adults were used. These animals were castrated, rumen fistulated and had an average weight of $527 \mathrm{~kg} \pm 41.47$. They were housed in individual pens equipped with feeders and drinkers. At the beginning of the experiment, the animals were dewormed, weighed and identified. The first ten days were used to allow the animals to adapt to the diets and pens. The experiment began shortly after the trial period and consisted of five evaluation periods of 11 days each, the last four of which were used to collect data. The diets consisted of a mixture of roughage, concentrate and minerals, which were formulated to be isonitrogenous $(13 \% \mathrm{CP})$, with a forage to concentrate ratio of 65:35, as recommended by the NRC (3) for maintenance (Table 1). Mineral salt was offered ad libitum in separate troughs and consisted of $240 \mathrm{~g} \mathrm{Ca}, 174 \mathrm{~g} \mathrm{P}, 5.270 \mathrm{mg} \mathrm{Zn,} 2000 \mathrm{mg} \mathrm{Mg}$, $1795 \mathrm{mg} \mathrm{Fe}, 1.740 \mathrm{mg} \mathrm{F}, 1.250 \mathrm{mg} \mathrm{Cu}, 100$ $\mathrm{mg} \mathrm{Co}, 90 \mathrm{mg} \mathrm{I}$ and $15 \mathrm{mg} \mathrm{Se}$, for each $\mathrm{kg}$ of product.

Tifton-85 Bermudagrass was used as forage, comprising $65 \%$ of the total diet. The animals were fed at $8: 00 \mathrm{~h}$ and $16: 00 \mathrm{~h}$, with daily adjustments of 10 to $15 \%$ of leftovers. The forage and concentrate were provided together. Daily consumption was determined by measuring the difference between the feed supplied and the feed left per animal during 
Table 1. Chemical composition of the experimental diets.

\begin{tabular}{|c|c|c|c|c|}
\hline \multirow[b]{2}{*}{ Analytical Fractions } & \multicolumn{4}{|c|}{ Ingredients } \\
\hline & $\begin{array}{l}\text { Corn } \\
\text { Meal }\end{array}$ & $\begin{array}{c}\text { Soybean } \\
\text { Meal }\end{array}$ & $\begin{array}{l}\text { Palm } \\
\text { Kernel } \\
\text { Cake }\end{array}$ & $\begin{array}{c}\text { Tifton } \\
-85 \\
\text { Hay }\end{array}$ \\
\hline Dry matter & 86.0 & 89.5 & 93.2 & 83.9 \\
\hline Mineral matter ${ }^{1}$ & 2.8 & 1.1 & 2.1 & 3.2 \\
\hline Ether extract 1 & 4.0 & 5.4 & 12.2 & 0.9 \\
\hline Neutral detergent fibre ${ }^{1}$ & 15.2 & 12.5 & 71.1 & 75.0 \\
\hline Acid detergent fibre ${ }^{1}$ & 4.2 & 11.2 & 26.1 & 13.3 \\
\hline Crude protein $^{1}$ & 8.0 & 46.6 & 13. & 8.0 \\
\hline NDIN $^{2}$ & 12.8 & 4.5 & 20.3 & 44.8 \\
\hline ADIN $^{2}$ & 6.4 & 3.28 & 19.3 & 8.12 \\
\hline Non-fibrous carbohydrates ${ }^{1}$ & 70.2 & 34.1 & 4.5 & 19.2 \\
\hline Cellulose $^{1}$ & 0.9 & 8.3 & 8.9 & 10.9 \\
\hline Hemicellulose $^{1}$ & 11.0 & 1.3 & 45.0 & 61.6 \\
\hline Lignin $^{1}$ & 3.3 & 2.9 & 17.1 & 2.4 \\
\hline Silica $^{3}$ & - & - & 0.4 & - \\
\hline
\end{tabular}

NDIN $=$ Neutral detergent insoluble nitrogen, ADIN = acid detergent insoluble nitrogen.

Values expressed in dry matter. ${ }^{2}$ Values expressed in Total Nitrogen.

${ }^{3}$ The analysis of silica was made only for the palm kernel cake

each collection period. A $5 \times 5$ Latin square experimental design was used, with five animals and five periods and controlled local factors. There were five evaluation periods for each of the five treatments, which consisted on the following inclusion levels of palm kernel cake: $0,7,14,21$ and 28\% (Tables 2 and 3).

Table 2. Percentages of ingredients in the diet (\% DM).

\begin{tabular}{lccccc}
\hline & \multicolumn{5}{c}{ Inclusion Percentage of Palm Kernel Cake } \\
\multicolumn{1}{c}{ Ingredient } & $\begin{array}{c}\mathbf{0} \\
\text { (control) }\end{array}$ & $\mathbf{7}$ & $\mathbf{1 4}$ & $\mathbf{2 1}$ & $\mathbf{2 8}$ \\
\hline Corn meal & 27.4 & 21.7 & 15.9 & 10.1 & 4.2 \\
$\begin{array}{l}\text { Soybean meal } \\
\text { Ammonium }\end{array}$ & 6.7 & 5.4 & 4.2 & 2.9 & 1.8 \\
sulphate & 0.1 & 0.1 & 0.1 & 0.1 & 0.1 \\
$\begin{array}{l}\text { Urea } \\
\text { Palm kernel cake }\end{array}$ & 0.8 & 0.8 & 0.8 & 0.8 & 0.8 \\
Hay & 65.0 & 7.0 & 14.1 & 21.1 & 28.1 \\
\hline
\end{tabular}

Samples of leftovers were collected on the last four days of each experimental period and subjected to a pre-drying process in a forced air chamber at $60 \pm 5^{\circ} \mathrm{C}$ for $72 \mathrm{~h}$. After this, composite sampling was performed and these samples were ground in a Wiley type mill with a $1 \mathrm{~mm}$ sieve, and analyzed for dry matter (DM), mineral material $(M M)$, crude protein $(C P)$, ether extract (EE) neutral detergent fiber (NDF), neutral detergent insoluble nitrogen (NDIN) and acid detergent insoluble nitrogen (ADIN) contents according to the methods described by the AOAC (4). The percentage of non-fiber carbohydrates (NFC) was calculated using the equation: NFC $(\% \mathrm{DM})=100-(\% \mathrm{MM}+\% \mathrm{CP}+\% \mathrm{NDF}+$ $\%$ EE) and the analysis of acid detergent fiber
Table 3. Chemical composition of the experimental diets.

\begin{tabular}{|c|c|c|c|c|c|}
\hline \multirow{2}{*}{$\begin{array}{l}\text { Analytical } \\
\text { Fractions }\end{array}$} & \multicolumn{5}{|c|}{$\begin{array}{c}\text { Inclusion Percentage of Palm Kernel Cake } \\
\text { in The Total Diet }\end{array}$} \\
\hline & 0 & 7 & 14 & 21 & 28 \\
\hline Dry matter & 84.9 & 85.3 & 85.8 & 86.3 & 86.7 \\
\hline Mineral matter & 1.0 & 0.9 & 0.9 & 0.9 & 0.8 \\
\hline Crude protein & 13.0 & 13.0 & 12.7 & 12.6 & 12.4 \\
\hline Ether extract ${ }^{1}$ & 2.0 & 2.6 & 3.1 & 3.7 & 4.3 \\
\hline NDF & 53.7 & 57.7 & 61.7 & 65.6 & 69.6 \\
\hline ADF & 10.6 & 12.0 & 13.5 & 14.9 & 16.4 \\
\hline $\mathrm{NIDN}^{2}$ & 32.9 & 33.6 & 34.2 & 34.8 & 35.4 \\
\hline ADIN $^{2}$ & 7.2 & 8.2 & 9.1 & 10.1 & 11.0 \\
\hline NFC & 23.0 & 21.2 & 19.3 & 17.5 & 15.6 \\
\hline Cellulose $^{1}$ & 7.9 & 8.4 & 8.8 & 9.3 & 9.8 \\
\hline Hemicellulose ${ }^{1}$ & 43.1 & 45.6 & 48.1 & 50.6 & 53.1 \\
\hline $\operatorname{Lignin}^{1}$ & 2.6 & 3.6 & 4.6 & 5.6 & 6.6 \\
\hline TDN & 58.6 & 58.0 & 56.3 & 53.4 & 51.6 \\
\hline
\end{tabular}

$\mathrm{NDF}=$ Neutral detergent fibre, $\mathrm{ADF}=$ acid detergent fibre, NDIN $=$ neutral detergent insoluble nitrogen, $A D I N=$ acid detergent insoluble nitrogen, NFC = non-fibrous carbohydrates, TDN=total digestible nutrients. 'Values expressed in dry matter. ${ }^{2}$ Values expressed on Total Nitrogen.

(ADF), hemicellulose, cellulose and lignin contents was conducted according to the methodology described by Silva and Queiroz (5).

Total digestible nutrient levels were obtained through adding the digestible fractions obtained by the equation proposed by Weiss (6): TDN $=\mathrm{dCP}+\mathrm{dDF} \times 2.25+\mathrm{NDF}$, where $\mathrm{dCP}, \mathrm{dEE}$, dNDF are digestible crude protein, digestible ether extract, and digestible neutral detergent fiber, respectively.

In order to determine the amount of fecal dry matter excreted, two stool samples per day were collected during four consecutive days at $8.00 \mathrm{a} . \mathrm{m}$. and 18.00 p.m. as these were the best times for predicting with greater accuracy the fecal dry matter production during the day. Stool samples, collected from the rectum of each animal, were stored at $-20^{\circ} \mathrm{C}$ until analysis. The indigestible NDF (iNDF) was used as an internal indicator to estimate the total digestion of dry matter. Samples of the different feeds, leftovers and feces were ground in a $2 \mathrm{~mm}$ sieve and incubated in situ in non-woven textile bags made from polyester 100 (100 g of raw material $/ \mathrm{m}^{2}$ final product) and in rumen cloth bags of tulle sewn with synthetic thread. The percentage of iNDF in the feeds, leftovers and feces was measured after $144 \mathrm{~h}$. The remaining material from incubation was subjected to an extraction with a neutral detergent solution and the residue was considered iNDF. Estimates of fecal excretion was obtained through the equation proposed by Smith and Reid (7): FE $=\mathrm{I} /[\mathrm{If}]$, where FE ( $\mathrm{g} /$ day) corresponds to the daily fecal excretion; I ( $g /$ day) represents the 
daily indicator offered/consumed, and [If] represents the concentration of indicator in fecal dry matter $(\mathrm{g} / \mathrm{g})$.

On the eighth day of each experimental period the animals were visually observed to assess their feeding behavior by recording the time spent on eating, ruminating and resting. Observations of these activities were made every $5 \mathrm{~min}$ for 24 consecutive $\mathrm{h}$. The observations began at 8.00 p.m. on the day feeding behavior was assessed in each experimental period, and the environment was lit with artificial light for night observations. Adaption to the night light was allowed during the four days preceding the day of observation.

Counting the number of chews (number/bolus) and recording the time spent ruminating for each bolus was performed by observing six ruminal bolus in two periods of the day, using a stopwatch. The total time spent ruminating was divided by the average time spent ruminating each bolus to obtain the number of cakes ruminated daily. Dry matter intake (DMI) and consumption of neutral detergent fiber (NDF)/cake variables were obtained by dividing the average individual consumption of each fraction by the number of ruminated bolus per day $(24 \mathrm{~h})$.

The intake (EI) and rumination (ERU) efficiencies of DM and NDF and total chewing time (TMT min/day) were calculated according to the method described by Burger et al (8), using the following equations: $\mathrm{EIDM}=\mathrm{DMI} / \mathrm{IT}$; EINDF $=$ NDF $/ I T$; where EIDM is the efficiency of DM intake (g DM intake/h), DMI $(g)$ is the daily intake of dry matter, NDF $(g)$ the intake of NDF, and IT the time spent on the daily intake; REDM = DMI/RT; RENDF = NDF/RT, where REDM is the rumination efficiency of DM (g DM cud/h), RT is the daily time spent ruminating $(h)$, RENDF is the rumination efficiency of NDF (NDF ruminated $g / h$ ), and RT is the time spent ruminating daily: TCT: + $\mathrm{TI}+\mathrm{RT}$; where TCT is the total chewing time (min/day).

Data analysis. The variables were subjected to variance and regression analysis using the Statistical Package for Social Sciences - SPSS (9), and a $5 \%$ level of significance. Linear and quadratic models were studied. Coefficient of determination (R2), $p$-values of t-test for regression parameters were used as criterion for choose the best fit.

\section{RESULTS}

A linear decrease in dry matter intake was observed $(p<0.05)$ (Table 4$)$, which yielded an intake average reduction of $1.37 \mathrm{~kg}$ per day for each $7 \%$ palm kernel cake included in the total diet. A linear decrease $(p<0.05)$ was observed for crude protein.

Despite the high levels of EE found in the palm kernel cake (Table 1), the consumption of this fraction was not altered by inclusion of the cake due to the low consumption of the concentrate.

The NFC intake, expressed as g/animal/day, $\% \mathrm{BW}$ and $\mathrm{g} / \mathrm{kg} \mathrm{MW}$ (metabolic weight), was reduced $(p<0.05)$ by the inclusion of palm kernel cake (Table 4) due to the reduction of nutrient contents in the diet (Table 3 ) and the reduction of DM intake.

Table 4. Average daily intake values of the nutritional fractions by cattle fed different levels of palm kernel cake, produced in the biodiesel extraction process, in the total diet.

\begin{tabular}{|c|c|c|c|c|c|c|c|c|}
\hline \multirow{2}{*}{ Intake } & \multicolumn{5}{|c|}{ Inclusion Percentage of Palm Cake } & \multicolumn{2}{|c|}{ Effect } & \multirow{2}{*}{$\mathbf{R 2}$} \\
\hline & $\mathbf{0}$ & 7 & 14 & 21 & 28 & $\mathbf{L}$ & $\mathbf{Q}$ & \\
\hline & \multicolumn{8}{|c|}{ Dry matter (DM) } \\
\hline $\mathrm{kg} / \mathrm{day}$ & 12.54 & 11.93 & 12.10 & 8.12 & 7.22 & $*$ & NS & 0.54 \\
\hline$\%$ LW & 2.35 & 2.26 & 2.28 & 1.47 & 1.34 & $*$ & NS & 0.82 \\
\hline \multirow[t]{2}{*}{$\mathrm{g} / \mathrm{kg} \mathrm{MW}$} & 110.65 & 110.13 & 108.78 & 71.26 & 63.56 & * & NS & 0.52 \\
\hline & \multicolumn{8}{|c|}{ Crude protein $(\mathrm{CP})$} \\
\hline $\mathrm{kg} /$ day & 1.22 & 1.15 & 1.02 & 0.60 & 0.35 & * & NS & 0.82 \\
\hline$\%$ LW & 0.23 & 0.22 & 0.19 & 0.11 & 0.07 & * & NS & 0.71 \\
\hline \multirow[t]{2}{*}{$\mathrm{g} / \mathrm{kg} \mathrm{MW}$} & 10.88 & 10.53 & 9.30 & 5.49 & 3.39 & $*$ & NS & 0.75 \\
\hline & \multicolumn{8}{|c|}{ Ether extract (EE) } \\
\hline $\mathrm{kg} /$ day & 0.52 & 0.82 & 1.02 & 0.84 & 1.03 & NS & NS & - \\
\hline$\%$ LW & 0.10 & 0.15 & 0.19 & 0.16 & 0.19 & NS & NS & - \\
\hline \multirow[t]{2}{*}{$\mathrm{g} / \mathrm{kg} \mathrm{MW}$} & 4.56 & 7.52 & 9.25 & 7.69 & 9.35 & NS & NS & - \\
\hline & \multicolumn{8}{|c|}{ Neutral detergent fiber (NDF) } \\
\hline $\mathrm{kg} /$ day & 8.25 & 8.71 & 9.38 & 7.62 & 6.06 & NS & * & 0.51 \\
\hline$\%$ LW & 1.56 & 1.64 & 1.77 & 1.64 & 1.14 & NS & * & 0.50 \\
\hline \multirow[t]{2}{*}{$\mathrm{g} / \mathrm{kg} \mathrm{MW}$} & 99.10 & 97.38 & 85.47 & 86.20 & 59.70 & NS & $*$ & 0.51 \\
\hline & \multicolumn{8}{|c|}{ Non-fibrous carbohydrates (NFC) } \\
\hline $\mathrm{kg} / \mathrm{day}$ & 2.45 & 1.25 & 0.68 & 0.32 & 0.11 & * & NS & 0.86 \\
\hline$\%$ LW & 0.46 & 0.24 & 0.13 & 0.06 & 0.02 & * & NS & 0.53 \\
\hline \multirow[t]{2}{*}{$\mathrm{g} / \mathrm{kg} \mathrm{MW}$} & 4.83 & 1.93 & 0.85 & 0.52 & 0.28 & * & NS & 0.93 \\
\hline & \multicolumn{8}{|c|}{ Total Digestible Nutrients (TDN) } \\
\hline $\mathrm{kg} /$ day & 8.96 & 8.99 & 9.10 & 6.87 & 6.00 & * & NS & 0.40 \\
\hline$\%$ LW & 1.69 & 1.70 & 1.72 & 1.30 & 1.13 & $*$ & NS & 0.40 \\
\hline $\mathrm{g} / \mathrm{kg} \mathrm{MW}$ & 79.38 & 82.58 & 82.16 & 62.81 & 53.82 & * & NS & 0.37 \\
\hline
\end{tabular}


The apparent digestibility of total dry matter, crude protein, ether extract, neutral detergent fiber and non-fibrous carbohydrates did not differ $(p>0.05)$ due to the inclusion of palm kernel cake (Table 5).

In relation to the behavioral activities of the animals, feeding, ruminating and resting activities (Table 6 ) were not influenced by the inclusion of up to $28 \%$ palm kernel cake in the concentrate $(p>0.05)$.

The number of chews per bolus also was not influenced by the inclusion of palm kernel cake.

A quadratic behavior was found for RENDF at the higher cake inclusion of $10.99 \%$ and linear downwards trends for EDMI, ENDFI and REDM (Table 6).

\section{DISCUSSION}

The decrease observed in intake of the palm kernel cake (Table 4) can be explained by the lower acceptability and the high fiber content of the cake. The content of neutral detergent fiber in the diet can reduce consumption primarily because of physical limitations, and this fraction in the palm kernel cake contained $70 \%$ of the DM in the feed. Moreover, the presence of small crystallized particles in this ingredient is evidence of the presence of silica, which is one of the factors responsible for reducing consumption of diets containing palm kernel cake. According to Van Soest (10), silica is a structural element present in most products and industrial by-products such as lignin, and thus can reduce fuel consumption and affect the digestibility of cell walls. According to the same author, silica is typically present when the ash content is greater than $2 \%$. Palm kernel cake used in this study contained $0.46 \%$ silica,

Table 5. Apparent digestibility coefficients of the nutrients in the total diets containing different levels of palm kernel cake, originating from biodiesel production, in Holstein $\times$ Zebu cattle.

\begin{tabular}{lcccccccc}
\hline $\begin{array}{c}\text { Coefficient of } \\
\text { Digestibility (\%) }\end{array}$ & $\mathbf{0}$ & $\mathbf{7}$ & $\mathbf{1 4}$ & $\mathbf{2 1}$ & $\mathbf{2 8}$ & $\mathbf{L}$ & Effect & CV (\%) \\
\hline Dry matter & 76.1 & 74.7 & 73.1 & 69.3 & 76.2 & NS & NS & 13.6 \\
Crude protein & 83.4 & 83.0 & 83.9 & 85.3 & 82.6 & NS & NS & 7.4 \\
Ether extract & 80.8 & 87.1 & 81.6 & 91.6 & 82.5 & NS & NS & 9.7 \\
NDF & 70.5 & 70.8 & 70.1 & 71.1 & 72.6 & NS & NS & 14.5 \\
NFC & 94.3 & 93.3 & 94.7 & 88.5 & 89.9 & NS & NS & 6.3 \\
\hline
\end{tabular}

$\mathrm{NDF}=$ Neutral Detergent Fiber, NFC $=$ non fibrous carbohydrates. $\mathrm{L}=$ linear effect, $\mathrm{Q}=$ quadratic effect. NS $=$ Not significant, $\mathrm{p}<0.01 . \mathrm{CV}=\mathrm{coefficient}$ of variation.

Table 6. Feeding behaviour parameters of Holstein-Zebu cattle fed diets with different levels of palm kernel cake that originated from biodiesel production.

\begin{tabular}{|c|c|c|c|c|c|c|c|c|}
\hline \multirow{2}{*}{ Item } & \multicolumn{5}{|c|}{ Inclusion Percentage of Palm Kernel Cake } & \multirow{2}{*}{ CV\% } & \multicolumn{2}{|c|}{ Effect } \\
\hline & $\mathbf{0}$ & 7 & 14 & 21 & 28 & & $\mathbf{L}$ & $\mathbf{Q}$ \\
\hline NDFI/meal (g/day) in $24 \mathrm{~h}$ & 14.6 & 13.1 & 15.5 & 14.6 & 17.4 & 13.3 & NS & NS \\
\hline Feeding (min/day) & 354.0 & 359.0 & 379.0 & 359.0 & 348.0 & 15.5 & NS & NS \\
\hline Rumination (min/day) & 523.0 & 553.0 & 493.0 & 505.0 & 455.0 & 13.0 & NS & NS \\
\hline Idle (min/day) & 563.0 & 528.0 & 568.0 & 576.0 & 637.0 & 11.7 & NS & NS \\
\hline Ruminated meal (no./day) & 566.4 & 601.1 & 524.5 & 573.9 & 498.2 & 14.9 & NS & NS \\
\hline Time chews/meal (s) & 55.4 & 55.2 & 56.4 & 52.8 & 54.8 & 13.2 & NS & NS \\
\hline EDMI $(\mathrm{g} \mathrm{DM} / \mathrm{h})^{1}$ & 2208.5 & 2010.3 & 1934.8 & 1376.1 & 1222.8 & 24.8 & $*$ & NS \\
\hline ENDFI $(\mathrm{g} \mathrm{NDF} / \mathrm{h})^{2}$ & 1465.6 & 1486.2 & 1536.0 & 1295.4 & 1133.0 & 26.9 & $*$ & NS \\
\hline $\operatorname{REDM}(\mathrm{g} \mathrm{DM} / \mathrm{h})^{3}$ & 1429.4 & 1317.2 & 1475.3 & 923.9 & 941.4 & 19.9 & $*$ & NS \\
\hline RENDF $(\mathrm{g} \mathrm{NDF} / \mathrm{h})^{4}$ & 959.2 & 966.3 & 1168.60 & 865.9 & 825.4 & 13.8 & NS & $*$ \\
\hline TCT $(\mathrm{min} / \mathrm{dia})^{5}$ & 877.0 & 912.0 & 872.0 & 864.0 & 803.0 & NS & NS & NS \\
\hline
\end{tabular}

NDFI = Neutral detergent fibre intake; EDMI = Efficiency of dry matter intake; ENDFI = Efficiency of neutral detergent fibre intake; REDM = Rumination efficiency of dry matter; RENDF = Rumination efficiency of neutral detergent fibre; TCT = Total chewing time of cattle fed diets containing different levels of palm kernel cake. NS = not significant, $\mathrm{p}<0.01$. DM = Dry matter, NDF = Neutral digestible fiber.

${ }_{1} \hat{Y}=-13.06780 x+2294.08$;

$2 \hat{Y}=-4.84782 x+1552.23800$

$3 \hat{Y}=-6.84667 x+1491.34760 ;$

${ }^{4} \hat{Y}=-0.11953 x^{2}+7.93602 x+925.11440$

$5 \hat{Y}=865.6$ 
which probably contributed to the observed reduction in the DM.

Reductions in the consumption of diets containing palm kernel cake were also observed by other authors, such as Silva et al (11), who worked with levels of up to $75 \%$ in concentrated feed for calves aged between 60 and 120 days, by Macome (12) and Costa et al (13), in experiments with up to $19.50 \%$ and $40 \%$ palm kernel cake for sheep, respectively, and by Carvalho (14), who assessed levels of $30 \%$ of palm kernel cake as feed for goats.

During the experiment, a diet selection by the animals, usually mainly fed hay rather than concentrate, when the levels of palm kernel cake increased, with a subsequent increase in NDF intake too was observed. The NDF intake showed a quadratic behavior $(p<0.05)$, with a maximum consumption of $8.46 \mathrm{~kg} /$ day for a $9.5 \%$ inclusion of palm kernel cake. At this point, the NDF intake as a function of PV peaked at $1.6 \%$, and ruminal filling caused by fiber was responsible for the reduced consumption of dry matter. The average intake of NDF in the present study was $1.13 \%$ of BW (body weight), which is within the range proposed by Van Soest (10) as being ideal, between $0.8 \%$ and $1.2 \%$ of cow BW, due to the factors previously mentioned.

Correia (15) noted that the inclusion of the latter resulted in the lowest DM intake $(p<0.05)$ compared to others. Similarly, Costa et al (11), who assessed levels of up to $40 \%$ palm kernel cake in sheep concentrate, observed that the addition of around $30 \%$ cake allowed for greater consumption of the fibrous fractions.

As shown in table 4, a linear decrease $(p<0.05)$ was observed for crude protein. This fact can be explained by the greater selectivity of animals in favor of hay, which contained a lower $\mathrm{CP}$ content than palm kernel cake (Table 1), besides the reduction observed in DM, with a resulting reduction in crude protein intake. The average CP intake in this study was $12.83 \mathrm{~g} / \mathrm{kg}$ BW, which was higher than that proposed by the NRC (3), $3.8 \mathrm{~g} / \mathrm{kg} \mathrm{BW}$, for cattle maintenance.

The lack of a significant effect on the consumption of $E E$, the most energetic fraction of the components of TDN, may have contributed to the reduction in TDN intake. This decrease was also reflected by the decrease in DM and NFC, which is capable of releasing a larger amount of energy via microbial fermentation in the rumen, being the fraction with the highest digestibility percentage.
The fact of NFC intake was reduced $(p<0.05)$ by the inclusion of palm kernel cake (Table 4) due to the reduction of nutrient contents in the diet (Table 3 ) and the reduction of DM intake, are consistent with Nunes (16), who tested levels of up to $19.5 \%$ palm kernel cake in the diet.

At this study, no difference in relation to digestibility was found. Others authors Nunes, (16); Ribeiro et al (17), who evaluated palm kernel cake as feed for sheep and cattle, respectively, and no differences in digestibility were found. Besides this, Costa et al (13) also noticed no difference in the digestibility coefficients when using levels of palm kernel cake instead of concentrate for feeding lactating goats and sheep, respectively.

The average digestibility of DM in this study was $74.23 \%$, which is considered high in comparison to the digestibility of by-products of fruit produced in the northeast of Brazil, from 24.12 to $76.97 \%$ (18). The absence of an influence of palm kernel cake on the digestibility of the diets may have been due to the high non-fibrous carbohydrate content of corn meal. Even with the reduction of this ingredient as the levels increased the palm kernel cake, corn meal was able to supply enough energy, so a significant effect on the digestibility of DM diets was not observed. Thus, the high content of fibrous fractions of palm kernel cake at the respective levels in the diet did not interfere with the DM digestibility.

Furthermore, the digestibility of NDF was not affected by the inclusion of palm kernel cake, even though the fiber constituents were different compared to corn and soybean (the treatment with $0 \%$ of palm kernel cake), with a higher lignin content (Table 1). The increase in the NDF percentage in the diets with higher levels of palm kernel cake was not reflected in higher intakes of NDF due to the high selectivity of animals fed diets with 21 and $28 \%$ palm kernel cake. This also explains why the values of consumption and digestibility of the ether extract showed no significant increase, despite the palm cake having high values of EE (Table 1 ). These results corroborate those found by Nunes (16), who also found no difference in EE digestibility.

NFC digestibility was not different due to the inclusion of palm kernel cake, as found in a study conducted by Silva et al (19) with the addition of $40 \%$ palm kernel cake in the diet of sheep. 
The results of behavioral activities are agreement with Carvalho et al (20), who found no differences in feeding behavior with levels of $30 \%$ palm kernel cake as feed for goats.

Although the reduction in intake was significant, the higher selectivity of the animals for diets with higher inclusion levels of the cake may have been responsible for the fact that feeding time (min/day) did not change. Although the animals consumed lower amounts of dry matter, they spent more time in selecting the diet.

The times observed for eating, ruminating and idling activities are within the range for standard feeding behavior in confined ruminants. The results were similar to Oliveira et al (21), who worked with cattle in a feedlot. These authors found times of $276 \pm 55.8 \mathrm{~min} /$ day; $482.4 \pm 43.8$ $\mathrm{min} /$ day and $606 \pm 126 \mathrm{~min} /$ day for the eating, ruminating and idling activities respectively.

The number of chews per bolus was not influenced by the inclusion of palm kernel cake, averaging 54.92 chews per bolus, which was considered adequate when the ratio of concentrate:roughage used was taken into account.

According to Carvalho (20), ingestion and rumination efficiencies are primarily affected by the animal's consumption and can cause implications for time spent on eating, ruminating and resting activities.

The effect of EDMI, ENDI and REDM (Table 6) may be explained by the fact that DMI was also decreased by addition of the palm cake. The total chewing time was not affected by the inclusion of palm kernel cake: the values found in this study were similar to those obtained by Correia (15), including $845.62 \mathrm{~min} /$ day for steers fed $100 \%$ palm kernel cake.

In conclusion, palm kernel cake can replace $28 \%$ of the corn and soybean meal concentrate in the total diet without adversely affecting the digestibility of dry feed or the fractions analyzed, with no change in the feeding behavior of the animals. However, the significant reduction in cake consumption in the present study may have implications for productive performance.

\section{REFERENCES}

1. Santos V C, Ezequiel JM B, Oliveira PSN. Consumo e digestibilidade em ovinos alimentados com grãos e subprodutos da canola. Rev Bras Saúde Prod Ani 2009; 10:96-105.

2. Watanabe PH, Ezequiel JMB, Galati RL. Indicadores internos indigestíveis para a estimativa das digestibilidades de dietas à base de coprodutos. Rev Bras Saúde Prod Ani 2010; 11:3.

3. National Research Council. Nutrient Requirements of Dairy cattle. Whashington: National Academy of Science; 2001.

4. Association of Analytical Chemist. AOAC. Official Methods of Analysis. 12th ed. Whashington: AOAC; 2000.

5. Silva DJ, Queiroz AC. Análise de alimentos: métodos químicos e biológicos. 3th edn Viçosa, MG: UFV; 2002.
6. Weiss WP. Energy prediction equations for ruminant feeds. In: Proceedings of Cornell Nutrition Conference For Feed Manufacturers. Ithaca: Cornell University 1999.

7. Smith AM, Reid JT. Use of chromic oxide as an indicator of fecal output for the purpose of determining the intake of a pasture herbage by grazing cows. J Dairy Sci 1955; 38:515-524.

8. Burguer PJ, Pereira JC, Queiroz AC. Ingestive behaviour in Holstein calves fed diets containing different levels of concentrate. Rev Bras de Zootec 2000; 29(2):236-242

9. Statistical Package for the Social Sciences - SPSS, Release 13.0. Chicago, 2004.

10. Van Soest PJ. Nutritional ecology of the ruminant. 2 ed. Ithaca: Cornell University Press 1994. 
11. Silva, FF, Pires AJV, Oliveira ARA. Torta de Dendê em Dietas de Bezerros Leiteiros Desmamados Precocemente. In: Annual Meeting of the Bras. Society Zooctec 2000.

12. Macome FM. Productive performance and carcass characteristics of lambs fed diets containing different levels of palm kernel cake. Rev MVZ Córdoba 2011; 16:26592667.

13. Costa DA, Ferreira GD, Araújo CV. Consumo e digestibilidade de dietas com níveis de torta de dendê para ovinos. Rev Bras Saúde Prod Anim 2010; 11:783-792.

14. Carvalho GGP, Pires AJV, Silva FF. Comportamento ingestivo de cabras leiteiras alimentadas com farelo de cacau ou torta de dendê. Pesqui agropecu Bras 2004; 39:919-925.

15. Correia $B R$, Oliveira $R L$, Jaeger $S M P L$, Bagaldo AR, Carvalho GGP, Oliveira GLC et al. Intake, digestibility and ruminal ph of steers fed diets with pies from the production from biodiesel to replacement soybean meal. Arq Bras Med Vet 2011; 63:353-363.

16. Nunes AS, Oliveira RL, Borja MS, Bagaldo AR, Macome FM, Silva TM, Barbosa LP, Pires L, Fróes A. Consumo, digestibilidade e parâmetros sanguíneos decordeiros submetidos a dietas com torta de dendê. Arch Zootec 2011; 60:1-10.
17. Ribeiro MS, Oliveira RL, Correia BR. Digestibilidade de dietas com tortas oriundas da produção de biodiesel para novilhos Holandês $x$ Zebu. In: Annual Meeting of the Bras. Society Zooctec 2010.

18. Pereira ES, Pimentel PG, Duarte LS, Villarroel ABS, Regadas Filho JGL, Rocha Júnior JN. Digestão intestinal da proteína de forrageiras e coprodutos da agroindústria produzidos no Nordeste brasileiro por intermédio da técnica de três estágios. Rev Bras Saúde Prod Ani 2010; 11:403-413.

19. Silva, HGO, Pires AJV, Cunha Neto PA. Digestibilidade de dietas contendo silagem de capim-elefante amonizado e farelo de cacau ou torta de dendê em ovinos. Rev Bras Zootec 2007; 36: 499-506.

20. Carvalho GGP. Cana-de-açúcar Tratada com Óxido de Cálcio em Dietas para Ovinos, Caprinos, Novilhas e Vacas em Lactação. [Ph.D. Thesis]. Viçosa, Brasil: Universidade Federal de Viçosa; 2008.

21. Oliveira AS, Campos JMS, Valadares Filho SC, Assis AJ, Teixeira RMA, Rennó LN, Pina DS, Oliveira GS. Substituição do milho pela casca de café ou de soja em dietas para vacas leiteiras: comportamento ingestivo, concentração de nitrogênio uréico no plasma e no leite, balanço de compostos nitrogenados e produção de proteína microbiana. Rev Bras Zootec 2004; 36:205-215. 